\title{
Proliferating Learning: Quanzhen Daoist Activism and Modern Education Reforms in Nanyang (1880s-1940s)
}

Une promotion taoïste de l'éducation moderne : l'activisme Quanzhen dans les réformes éducatives à Nanyang (1880-1949)

崇道興學：清末民初南陽玄妙觀對現代教育改革的積極參與

Xun Liu

\section{(2) OpenEdition}

\section{Journals}

Electronic version

URL: http://journals.openedition.org/extremeorient/184

DOI: 10.4000/extremeorient. 184

ISSN: 2108-7105

Publisher

Presses universitaires de Vincennes

\section{Printed version}

Date of publication: 1 November 2011

Number of pages: $53-90$

ISBN: 978-2-84292-334-1

ISSN: 0754-5010

\section{Electronic reference}

Xun Liu, « Proliferating Learning: Quanzhen Daoist Activism and Modern Education Reforms in Nanyang (1880s-1940s) ", Extrême-Orient Extrême-Occident [Online], 33 | 2011, Online since 01

November 2014, connection on 19 April 2019. URL : http://journals.openedition.org/extremeorient/184 ; DOI : 10.4000/extremeorient. 184 


\title{
Proliferating Learning: Quanzhen Daoist Activism and Modern Education Reforms in Nanyang (1880s-1940s) ${ }^{1}$
}

\author{
Liu Xun
}

On the seventh day of the eighth moon in 1906, the imperial historians who were in charge of the compilation of the Veritable Record the Qing Dynasty (Qing shilu) which assiduously documents the thrones and their courts'significant policy action and administrative decisions, made the following entry in the Record:

For his donations to start schools, his Majesty grants Yao Xiangrui, the Daoist cleric of the Monastery of the Dark Mystery (Xuanmiao guan) in Nanyang of Henan a temple frontpiece entitled "Quanzhen (Daoists) Proliferates Learning (Quanzhen guangxue)."

Recorded among many other similar imperial decrees, the Guangxu court intended the grant to encourage wide support for the court's initiatives in starting and spreading modern popular education throughout the realm. A few years later, another renowned Quanzhen Daoist Palace of the Three Primogenitors (Sanyuan gong) in Guangzhou also received a similar imperial commendation for its contribution toward building new schools in that city. ${ }^{2}$

1. I thank the CCK Foundation, Agence Nationale de la Recherche, and Rutgers Research Council for providing several grants in support of the field research for this study. Earlier versions of this article were presented at UC Berkeley (2007), Columbia University, Huazhong Normal University, Chinese University of Hong Kong, Université Lumière Lyon 2, and University of Virginia (all in 2009). I am grateful to the audience at these institutions, and in particular for the helpful critics and suggestions by Susan Naquin, Vincent Goossaert, Paul Katz, David Johnson, Robert Hymes, John Lagerwey, Lai Chi Tim, Christian Henriot, Fu Haiyan, Mei Li, and Clarke Hudson. I also thank Dr. Ji Zhe and the external reviewer for their useful editing which has improved the manuscript. I alone am responsible for any errors herein.

2. See "Dezong shilu" in Qing shilu, j. 563, p. 449. There are also many other imperial commendations for Buddhist clerics, local business as well as Confucian literati who 
In Nanyang, a relatively remote prefectural seat and trade town located in southwestern corner of the North China plains, this imperial gesture of favor was enthusiastically received and celebrated with great fanfare by the Xuanmiao Monastery's clergy and the local community alike. To commemorate this glorious occasion, abbot Yao, the central figure of the imperial recognition, had the imperially inscribed placard entitled "Quanzhen (Daoists) Proliferating Learning" framed conspicuously on the frontpiece of the imposing Scriptorium (cangjing ge) located in the eastern wing of the Nanyang monastery, and another frontpiece entitled "With Benefits for the Central Plain (Hui jia Zhongzhou)" affixed to the entrance tower to the monastery, as if to remind both his fellow clerics and the local scholarly elites who frequented his monastery of the extensive roles and contribution he and his monastery had made toward local modern education by starting and running the new schools a few years earlier. ${ }^{3}$

To many who work on modern Chinese history and religion, the mere juxtaposition of Quanzhen Daoism with modern education is sufficiently odd, if not outright bizarre. This sense of oddity is well-founded in the fact that general histories of modern education of China have so far largely disregarded any Daoist participation in modern educational reforms since the late Qing. ${ }^{4} \mathrm{To}$ me, this sense of the strange stems from our long exposure to the May Fourth inspired historiography which has tended to view traditional religions such as Daoism as an anti-modern conservative establishment inimical to change and modernity. It is also rooted in our general lack of knowledge about the subject. Except for a few studies, we know next to nothing about how traditional religious

made monetary and land contributions towards building new and western styled local schools.

3. The description of the physical layout of the monastery is based on the maps and oral history materials gleaned from several contemporary sources on Nanyang. See "Nanyang Xuanmiao guan shilue”; "Guanyu Xuanmiao guan”; Xi Zheng, "Nanyang Xuanmiao guan,” p. 58-60; Shi Zongrui, "Xuanmiao guan xiao zhi,” p. 108-131; and Yin Dejie, Lao Nanyang. It is not clear yet as to who conferred the second placard affixed to the gate tower of the monastery, as the record in Qing shilu makes no mention of it.

4. A cursory review of the major general histories of modern Chinese education reveals no mention at all of Daoist involvement in the late Qing and early Republican educational reforms. See Hsiao, The History of Modern Education in China; Edmunds, Modern education in China; Biggerstaff, The Earliest Modern Government Schools in China; Shu Xincheng (comp.), Jindai Zhongguo jiaoyu shi ziliao; Bastid, Aspects de la réforme de l'enseignement; Ch'en Ch'ing-chih, Zhongguo jiaoyu shi; Ichiko Chūzō, "Educational Reform"; and most recently, Bai Limin, Shaping the ideal child. 
institutions like the Xuanmiao monastery dealt with the extensive changes of the late Qing and the early Republican eras, especially modern education. ${ }^{5}$

Though little known to scholars and the public, the Xuanmiao monastery in Nanyang had been a major Quanzhen Daoist public temple from the mid17th century to the early 20th century. The Quanzhen Daoist sect was first founded in the mid-12th century in the Central Plains by Wang Zhe (Daoist style: Chongyang, 1112-1170) and his leading disciples. Its lineages and temple network began to take roots throughout North China from the late 12th century onward. The Nanyang Xuanmiao monastery was first built at an old Handynasty era temple site outside the northerwestern wall of the city sometime under Khubilai reign (1260-1294). During most part of the Ming dynasty, the Xuanmiao monastery also housed the daoji si, a Ming state sanctioned Daoist regional administrative agency governing local Daoist temples and clerics affairs throughout the Nanyang prefecture. By the time of the Qing conquest of the North China plains in 1640s, the monastery had grown significantly both in size and population. A 1658 temple stele inscription reveals that the Quanzhen Daoist clerical ranks at the time had grown well over 60, a number which exceeded the Ming state stipulated per prefecture quota by $50 \%$. By the late 19th century period, the clerical population at the monastery had swelled to several hundreds at times. ${ }^{6}$ As I have shown elsewhere, the monastery's prominence as a Daoist public temple throughout Qing period (1644-1911) is intricately linked to its close collaboration with the Qing state's struggle to establish and defend its power and legitimacy at various critical junctures: first at the time of the Qing conquest and consolidation in Nanyang during the mid-17th century, then at the height of the suppression of the White Lotus millenarians in the late 18th century, and most recently in the defense of Nanyang against the Taiping and the Nian rebels who nearly toppled the dynasty during the mid-19th century. ${ }^{7}$

In this article, I continue to explore the Daoist collaboration with the Qing imperial and the Republican states by focusing on its role in starting and managing local modern schools and vocational training programs targeted at promoting

5. These few exceptions include Holmes Welch's early study of the Buddhist involvement in establishing and operating modern schools in Jiangnan and other regions during the late Qing and early Republican era (The Buddhist Revival in China), and most recently Vincent Goossaert's Taoists of Peking which shows the continued relevance of Daoist clerics as a social and professional group intimately engaged with the modernizing society in Beijing between 1800 and 1950.

6. See Yang Jing, "Zhang dajiangjun shouyi kugu bei," 1658 stele rubbings in my collection; and Yu Yinlin, "Xibei yuanji” in Pan Shoulian (comp.), Nanyang xianzhi, 12.22b-24a.

7. Xun Liu, "General Zhang Buries the Bones"; and also "In Defense of the City and the Polity." 
local education for the general population in Nanyang. Based on evidence which I have developed from local archives, oral histories, temple gazetteers, and epigraphic materials, I show that the Quanzhen Xuanmiao monastery and its leading clerics were actively involved in promoting and implementing the stateinitiated modern education reforms in Nanyang from the late 1890s to the1940s. In understanding the motives of the Quanzhen activism in modern education in Nanyang, I argue that the Quanzhen monastic involvement in the local modern education should not be seen in simplistic terms of self-preservation, or cynic opportunism in the face of the modern state expansion. Rather, such monastic activism must been understood as a natural extension and expression of the Nanyang Quanzhen monastic self-identity and its legacy of collaboration with the Qing polity and the Nanyang local community over two and half centuries. Indeed, the early Qing pattern of the close Quanzhen Daoist collaboration with the state and local community was further strengthened through the Quanzhen monastic activism in the late Qing and the Republican state-initated reform programs, especially in modern education in Nanyang.

While my focus on the Xuanmiao monastery in Nanyang here is partly driven by the preponderant source materials I have collected there, the Quanzhen Daoist participation in the late Qing and early Republican era educational reform was by no means exclusive to the Nanyang region alone. Indeed, preliminary evidences also show that Quanzhen clerics and lay activists at other major universal monasteries (shifang conglin) in Shenyang, Tianjin, and Wuhan were also actively involved in promoting and operating new schools the late Qing and early Republican periods. ${ }^{8}$ But the Nanyang case will illustrate the overall pattern of Quanzhen activism at the local level in China's modern transformation of the late Qing and the early Republican period.

8. For instance, at the Taiqing gong in Shenyang, abbot Ge Yuetan (1854-1934) and his monastery sponsored a new primary school at the monastery. See Igarashi Kenryu, "Katsu Gettan rōshi no tsuioku" in his Dōkyō sōrin Taishingū shi, p. 281-287. Abbot Chen Mingbin (1854-1936) of the White Cloud Monastery in Beijing who began his Daoist career at the Shenghai gong near Tanggu of Tianjin was also known for his activism in promoting new popular education for the children near his abbey. In the late Qing Wuchang, the clerics and their lay activists and donors at the Quanzhen monastery Changchun guan were also known for their involvement in starting the new school there. Three prominent disciples of the monastery were responsible for establishing the primary school for the commoners at one of the monastery's estates. See "Cai Fuqing, Xiao Yuqian, Liu Zongsan shanshi hezhuan," in Changchun guan zhi, 2.31a-b. 


\section{The Xuanmiao Monastery and the State in the Late Qing Era}

Because of its history, prestige, and wealth accumulated over a period of more than two hundred years since the Qing conquest, the Xuanmiao monastery had by the mid-19th century established itself as not only a major Quanzhen universal monastery in central China, but also as a Daoist temple with considerable political influence, cultural weight, and economic power in Nanyang. The rapidly changing political, economic and social conditions between the late 19th and early 20th centuries brought both opportunities and challenges to the old Quanzhen monastery, inspiring its leading clerics to develop new strategies in dealing with the changing times, in preserving, re-creating, and asserting the Quanzhen Daoist identity and power by actively participating in various local modernizing projects.

In Nanyang, the Xuanmiao monastery and its clerics weathered a host of political and military regimes, from the fast-expanding late Qing local government from the 1880s to 1912, through a sleuth of local hegemons and warlords with different goals, agendas and interests in the first two decades after the 1911 revolution, to the modernizing Republican state authorities who increasingly strove for total domination of the Nanyang society between 1928 and 1949. As these regimes developed and implemented different policies toward Daoism as a religion, the Xuanmiao monastery and its clerics developed different initiatives, programs and strategies in response.

In the aftermath of the Taiping war, the Qing state, under the initiatives of its local and regional officials such as Zeng Guofan (1811-1872), Li Hongzhang (1823-1901), and others began massive efforts at restoring and consolidating the Qing polity through a host of projects aimed at rebuilding the Qing moral and cosmic order, and revitalizing local and regional economy throughout the empire. These efforts resulted in what has since been known as the Tongzhi Restoration (Tongzhi zhongxing). In the four decades leading up to the Republican Revolution in 1911, the Qing court adopted a host of statecraft reforms in such areas as education, agriculture, finances, military, law, and government. While these reforms were aimed at strengthening and consolidating the Qing state and its political power and moral order, they also ushered in China's initial process of modernization by introducing Western learning, technologies, factories, shipping, railroads, and arsenals. ${ }^{9}$

In Nanyang, the late Qing local officials began to push for these reform programs in education, agriculture, social welfare, and other areas, the Xuanmiao

9. For the Tongzhi restoration and the ensuing "Self-strengthening movement," see Wright, The Last Stand of Chinese Conservatism. 
monastery and its leading clerics played an active and sometimes leading role in implementing the local modernization projects by either collaborating with the Qing local officials, or initiating programs entirely on their own to shape the course of modernization in the region. Instead of being an obstacle or a dragfoot to the modern reforms as conventionally imagined, the Xuanmiao monastic leaders and clerics often acted as proactive players in establishing and operating the new institutions in a host of reform projects, especially in modern education in Nanyang. These monastic efforts continued to follow the long-established pattern of close collaboration with the Qing state and the local community. Their motives seem to have stemmed as much from the Quanzhen monastic legacy of collaboration and public service, as from the practical and strategic need to preempt the threat of the Qing and Republican state expropriation of temple properties.

The man who led the Xuanmiao monastery's activism in the new education reform in Nanyang was the politically conservative and Qing loyalist abbot Yao Xiangrui who was also known by his secular name Yao Aiyun (?-1912). He succeeded abbot Zhang Yuanxuan (1812-1887) as the new prior (jianyuan) at the Xuanmiao monastery in 1885, and then quickly rose to become its abbot sometime in the 1890 s when he successfully presided over a consecration rite at the monastery which was a major means of ritual and moral legimitation and empowerment for rising clerics within the Quanzhen Daoist order. Yao was a native of Shaanxi. Having lost his parents and relatives at the age of 17 to the Muslim uprising which broke out in the region in the early 1860 s, Yao joined the Qing forces under the command of the Manchu general Duolong'a (literary style: Litang, 1817-1864). ${ }^{10}$ Yao saw action in a score of battles, and avenged his parents'death in one of the campaigns against the Muslim militants. His courage and exploits in battle earned him a promotion to the high rank of a brigade commander (youji). He was appointed chief of Duolong'a's personal guards. But after the general died of battle wounds suffered from a major engagement with the Muslim forces in Shaanxi in late spring of 1863, Yao abandoned his command. He changed his name and entered the Daoist scared Mount Lao in Shandong where he became a Daoist renunciant. Like many Quanzhen Daoists at the time, Yao toured all major Quanzhen Daoist monasteries in Jiangnan and North China. He later sailed across the Bohai sea, and sojourned at the main Quanzhen public monastery of Taiqing Palace (Taiqing gong) in Fengtian in

10. For a brief history of the causes of the Muslim uprising and the Qing campaigns against them in the northwestern provinces of Gansu and Shaanxi during the 1860s and 1870s, see Li Enhan, “Tongzhi nianjian Shaan-Gan Huimin shibian.” For Duolong'a's life and career, see Li Yuandu, "Duo Zhongyong gong bie zhuan." 
Manchuria. ${ }^{11}$ His next travels took him to the Qing capital where he settled as one of the senior clerics at the White Cloud Monastery (Baiyun guan). There Yao developed close ties with many fellow Daoists, among whom was the erstwhile fellow Qing officer-turned Quanzhen cleric Xie Baosheng (literary style: Zilan,?-1911). Like Yao, Xie had also served as an officer in the Qing Green Standard army, but now sought sanctuary from his own career setbacks in the Quanzhen Daoist monastery the capital. Clearly popular, Yao rose quickly through the Quanzhen monastic ranks. By the early 1880s, he was selected to serve as the prior of the prestigious monastery in the capital. At the time, abbot Zhang Yuanxuan who headed both the White Cloud Monastery and the Xuanmiao monastery in Nanyang was sojourning in the capital. It is highly likely that Yao developed close ties with abbot Zhang during the latter's stay in the capital. In 1885, Yao left his post as the prior of the White Cloud Monastery in the capital, and journeyed southward to Nanyang to head the Xuanmiao monastery there, probably at the behest of abbot Zhang. ${ }^{12}$

In Nanyang, Yao's military credentials and his old ties with the Qing officialdom soon connected him with the local Qing political and military establishment. Years after Yao's arrival in Nanyang, his friend and fellow Quanzhen cleric, Xie Baosheng, also came out of his sojourn at the White Cloud Monastery at the time of the Boxers'uprising, and rejoined the Qing military as a senior commander of the modernized Qing forces stationed in northern Henan province. By 1909 when Xie was given the command of the Nanyang Divisional Command (Nanyang zongzhen) in the province, Yao and Xie had resumed their friendship, and the Nanyang monastery's ties with the Qing local political and military officials also reached its apex. Indeed so much so that these close ties with the Qing local establishment were seen by both the anti-Qing activists and contemporary gazetteers in China as signs of Quanzhen clerical venality, corruption, and anti-modern conservatism. In the contemporary local sources, Yao was typically described as a corrupt Quanzhen Daoist who "wasted the monastic wealth in wining and dining" the Qing officials for his personal gains. ${ }^{13}$

But the abbot's relationship with the Qing local establishment clearly extended beyond the banquet table to encompass a whole range of close cooperation and support for the Qing state. At the height of the Boxers uprising which began to spread from Shandong and Hebei to regions of Henan in the summer of 1900, abbot Yao did something highly reminiscent of what his predessor Zhang Yuanxuan did during the anti-Taiping campaigns nearly four decades earlier. Yao

11. Yu Yinlin, "Xibei yuan ji."

12. Taishang lü mai yuanliu Longmen chuanjie puxi.

13. Wang Pengzhou, "Xie laodao qicheng ziqiang ji." 
and his monastery provided active support to Qing local officials and literati in fortifying the Nanyang city wall and training local militia. ${ }^{14}$ But more relevant to our story is Yao's active involvement in the Qing state-initiated eduation reforms.

\section{Temple Property for New Schools: Late Qing Education Reforms 1898-1911}

In the aftermath of the Sino-Japanese War in 1894, many reform-minded Qing court officials and literati began to advocate for wholesale reform projects aimed at revamping and modernizing the Qing state. In 1895, with support and sponsorship from ranking Qing state officials, Kang Youwei (1853-1927) and other leading intellectuals established the "Self-strengthening Society (Qiangxue hui)" in Shanghai, and actively promoted their reform agenda in their widelyread journals.

In response to the public call for change, the Qing court under the direction of the Guangxu emperor began to devise and implement a host of reforms to modernize its political, legal, military, and educational systems. In the spring of 1898, before the height of the One-hundred Day reforms, Zhang Zhidong (18371909), an earlier supporter of the Shanghai Self-strengthenning Society and the powerful governor general of the Hu-Guang region, and a skilled operator in the Qing court politics, published an influential reform proposal which sought a more moderate alternative to the radical reform plans by Kang Youwei and others. In his “Appeal to Learning (Quanxue pian)," Zhang rejected the radicalist call for more popular rights and the establishment of a parliamentary system. While insisting on preservation of the traditional Confucian moral and political order, Zhang advocated for the introduction of Western new learning, technologies, and institutions as means to strengthen the Qing state's political institutions and core values. ${ }^{15}$ One of the key visions put forth by Zhang Zhidong in his memorial is to use the existing Buddhist and Daoist temples and their property for establishing the new national education system. In an impassioned memorial to the throne, governor general Zhang proposed to convert existing Buddhist and Daoist temples into the new schools:

14. For abbot Zhang's career, especially his role in the Qing defense of Nanyang, see Goossaert, The Taoists of Peking, p. 171-175, and Xun Liu, "In Defense of the City and the Polity."

15. For Zhang and other conservatives'efforts at defining the Qing educational reform, see Ayers, Chang Chih-tung and Educational Reform, and Su Yunfeng, Zhang Zhidong yu Hubei jiaoyu gaige. 
Some would say, the current academies of our prefectures and counties all lack sufficient funds and have only small school buildings. This is especially so in small counties which lack any resources. How can they afford to support faculty and students, and buy books and instruments (of the new schools)? I say: a county can use the lands of local philanthropic halls, and the proceeds from local temple fairs and theatrical plays to build these schools; whereas a clan can use the tribute income of its lineage hall to build the schools. Admittedly, the number of schools we build this way are still rather limited. So what shall we do? I say: we can remodel Buddhist and Daoist temples to build schools. Nowadays, these temples easily exceed several tens of thousands in number. Our metropolitan capital and provincial cities each have hundreds of them. In a large prefecture, they number in scores, and even in a small county seat, there are usually over a dozen of them. All of the temples possess endowment lands. Their properties have all come from donations. If they are converted into schools, then the schools will have both buildings and endowment lands. This is also an expedient and easy strategy (for building the new schools). ${ }^{16}$

While the more radical initiatives by Kang and others suffered a major setback in the 1898 summer coup, Zhang's reform proposal, especially his vision of expropriating Buddhist and Daoist temples to build new schools, was embraced by the conservative faction of the Qing court after they took control via a coup. In 1904, as part of its national reform programs, the court abolished its traditional civil service examination system, and announced plans for adopting a new educational system as a means of training its ruling elite. To accomplish its educational reforms, the Qing court adopted Zhang Zhidong's proposal, and developed a host of new policy initiatives encouraging local and regional governments in expropriating temple property for buiding the new schools. Between 1902 and 1903, Zhang Zhidong and several of his colleagues devised and issued a series of directives which set forth the procedures and standards for establishing and managing the new national education system. As Zhang and fellow officials continued to implement their reform agenda in their respective jurisdictions, Zhang's proposal for "converting temples into schools (miaochan xingxиe)" also became the Qing state policy for building the new national education system. It continued to exert influence on the Nationalist state policy toward religion and education after 1911. ${ }^{17}$

Faced with the encroaching state determined to consolidate and expand its power and political legitimacy through various modernizing projects, Buddhist and Daoist monasteries and temples throughout the country scrambled to

16. For a recent study in English of the late Qing state expropriation of temple property for modern education, see Goossaert, "1898."

17. Lin Zuojia, "Qing mo Min chu miaochan xingxue"; and Wang Leiquan, "Dui Zhongguo jindai liangci miaochan xingxue de fansi." 
respond. But lacking integrated organization and resources, and separated by sectarian and geographic divides among themselves, the Daoists did not develop any nationally uniform consensus on how to respond the state challenge. Even after the 1912 establishment in Beijing of the first national Daoist Association (Zhongyang Daojiao hui) by a few major Quanzhen monasteries, the majority of the Daoist temples were left on their own to deal with the state expansion in their localities. In most cases, such efforts at building new schools have largely been perceived as feeble and ineffective attempts to preempt or prevent the Qing state expropriation of temple property. In some cases, Buddhist and Daoist clerics were reported to have destroyed the newly established schools at their temples out of sheer frustration and despair. Partly because of these monastic resistance, even the Buddhist and Daoist efforts in establishing new schools are often seen as cynical, opportunistic, and driven by monastic selfinterest, or alternatively as actions of largely powerless victims to the modern state expansion in education. ${ }^{18}$

In Nanyang as elsewhere, local officials, literati, and merchants responded to the late Qing state initiatives in new education in earnest. Shortly after the Qing court issued its regulations on the new schools in 1902, the Nanyang magistrate converted the traditional prefectural Chongzheng academy (Chongzheng shuyuan) into the new Chongzheng Advanced Primary School (Chongzheng gaodeng xiao xuetang) to conform to the new educational standards. That same year, a prominent local merchant set up a new primary school in the large bordertown of Zijing Pass in Xichuan county, 80 miles west of the Nanyang city. Two years later, in 1904, Zhang Jiamou (1874-1941), a prominent local literatus and educator set up the Jingye Primary School (Jingye xiao xuetang) in Nanyang. More new schools, including high schools, and normal schools were established in Nanyang by a variety of local sponsors from local magistrates, to merchant guilds, elite literati members, and Buddhist and Daoist temples in that same year and the years to follow.

The Xuanmiao monastery under the leadership of abbot Yao Aiyun was among the pioneers to establish new schools for local residents in the city. Within one year from 1905 to 1906 , the monastery alone set up two primary schools in the northern district of the Nanyang city. The monastery's new schools may

18. For a brief description of the Buddhist and Daoist efforts in building new schools, see Lin Zuojia, "Qingmo Minchu miaochan xingxue zhi yanjiu," p. 40-45; and also Liu Chengyou, "Luelun miaochan xingxue." To prove his point about the extensive devastation of the Qing and the Republican policies to Daoism, Liu provides statistical data from the 1929 Taian county survey to show that of the 348 new schools, 67 were established at Buddhist temples, 20 at the Muslim mosques, and the majority of 203 were built at the "popular" (and Daoist) temples. 
appear to be just a countermeasure against the Qing policy of "converting or using temples for starting schools," preempting the threats of potential state seizure of temple lands and property.

But in Nanyang, evidences suggest that the Quanzhen monastic interest in local education was more than just a state-coerced response in haste, or an opportunistic preemption of the Qing state expropriation campaign at the time. Instead, the Xuanmiao monastic activism in building the new schools in Nanyang can be better understood in the context of the monastery's legacy in local schooling. Indeed, the Xuanmiao monastic involvement in promoting local education predated the Qing state temple expropriation policies by quite a few years.

Around the mid 1890s, abbot Yao Aiyun spent a fortune of 11,700 taels of silver in building a traditional private school (sishu) in the neighborhood of the northern quarter of the city, as part of his monastic expansion program in Nanyang. At the time, it was one of the seven largest private schools in the prefectural town of Nanyang, comprised of several buildings of twenty four rooms. Though details are yet to come by, this monastery-funded private school catered to local children whose parents could well afford the tuitions the monastery charged. Almost concurrently, Yao and his monastery set up two free village schools (yixue) in the neighborhoods near the north gate. These two free schools were intended for children of poor families in the city district This early Quanzhen clerical initiatives in managing the local popular education drew praise from Yu Yinlin (?-1904), the former governor of the Henan province and a patron of the Xuanmiao monastery. Yu stayed at the monastery in 1901 to recover from an illness, and was well-aware of the monastery's early efforts in promoting local popular eduction. That year when he stayed at the monastery, Yu observed first-hand Yao's involvement in running these local schools. According to $\mathrm{Yu}$, abbot Yao showed a strong interest in the daily management of the free village schools, and involved himself in recruiting teachers trained in the new Western learning to provide instruction at these schools. ${ }^{19}$

So when the Qing state first began to push for new schools throughout the country in 1904, Yao's earlier efforts in promoting local education cohered with the Qing state goals of modernizing the country's local popular education system. Together with the monastery's long tradition of collaboration, Yao's early activism also legitimized and empowered the Daoist monastery as the Qing state partner, if not an outright agent, in spearheading the state efforts in building and managing the new modern schools in Nanyang. In October of

19. Yu Yinlin, "Xibei yuan ji." For Yu's life and career, see his entry in Jin Liang (comp.), Guang Xuan liezhuan, p. 215-217. 
1905 shortly after the Qing court issued the decree to abolish the civil service examination system and to implement the new school standards, abbot Yao and his monastery set about converting the two free schools into the new schools.

In the city, the first primary school set up by the Xuanmiao monastery on the main street near the north city gate was also named after the monastery. Following the 1904 court-sanctioned regulations for the new schools, the Xuanmiao Monastery School (Xuanmiao guan liangdeng xiaoxue) consisted of the two departments, the Junior Department (Chudeng xiaoxue) which admitted pupils from ages 7 to 12, and the Senior Department (Gaodeng xiaoxue) which admitted older students aged from 12 to 16 from the Nanyang region. With an annual budget of only 600 taels of silver, the school managed to admit over 117 students the same year, nearly twice as many as the total enrollment at its counterpart: the state-funded and literati-run Chongzheng Advanced Primary School which had an annual budget of 1,000 taels of silver. The monastery retained Wang Yanbin, a prominent local scholar, to serve as the principal. In addition, eight teachers were recruited as the faculty to teach the required full curriculum of classes, ranging from traditional Confucian classics through maths and science to history and geography. ${ }^{20}$

In January of 1906, three months after the first new school went into operation, abbot Yao and his monastery converted its other private school on the main street within the northeastern quarter of Nanyang into their second new school which they named as the Yuanzong School (Yuanzong xuetang). As with its first new school, the monastery's second new school operated on a small annual budget of 400 taels of silver generated from the monastic landholding and real estate in the city. Like its sister school, it was also divided into junior and senior departments. With Ji Yongtai, a local literatus retained as its principal, the second school had four teachers as its regular faculty, and admitted a total of 96 students in 1906. ${ }^{21}$ Outside Nanyang at the historical Broad Vista township, the prior of the Palace of the Three Primordials (Sanyuan gong), an affifliated branch temple to the Xuanmiao Monastery, wasted no time in establishing its own new primary school for children living in that commercial township. Named "A Gathering of the Three Primary School (Sancui xiaoxue)," the new school operated on an annual budget of 400 taels of silver and also admitted nearly 100 students from the market town and its suburbs. ${ }^{22}$ These primary schools funded

20. I have yet to locate the actual textbooks used for the early schools in Nanyang. Here I am relying on the stipulated school regulations of 1904 for information about the new school curriculum. See Zhang Baixi et al., Zouding xuetang zhangcheng. See also Ichiko Chūzō, "Educational Reform," p. 439-443.

21. Nanyang shizhi, p. 654-646.

22. Shi Zongrui, “Xuanmiao guan xiao zhi,” p. 111, 119, and p. 121-122. 
by the Quanzhen monasteries figured prominently in the expansion of modern elementary education in the Nanyang region (see appended chart).

The Xuanmiao monastery and its affiliated temples were by no means alone in their proactivism in establishing and running modern schools for the local communities. Their Buddhist counterparts, especially those well-endowed monasteries inthe Nanyang region, were also closely involved in the early phase of building new schools. The famed Buddhist Puti Monastery (Puti si) in Zhenping county west of Nanyang traced its monastic roots to the mid-7th century. By the late imperial period, the Buddhist monastery had developed an extensive local temple network throughout the Nanyang region. With its rich landholdings, it counted as one of the wealthiest Buddhist temples in the Central Plain. Prior to the time when the Qing local officials in Nanyang first launched their initiatives in modern education in Nanyang, the Buddhist monastery had been operating scriptural recitation and study classes for its young clerics. In the spring of 1905, the Puti monastery, like its Daoist counterpart in Nanyang, built the first new modern primary school named "School of Salvational Relief (Jiuji xiaoxue)" at the Temple village (Si zhuang) in Zhenping county. ${ }^{23}$

In Nanyang, quite a few other local wealthy temples like the Xuanmiao and the Puti monasteries also responded proactively to the Qing state initatives in modern education, and made a great contribution to building new schools locally. As shown in the appended table, while the Daoist-run schools numbered only two out of a total nine modern primary schools established within the Nanyang city, by Qing local officials, merchant guilds, or philanthropic organizations and inviduals between 1902 and 1910, they stood out in terms of the size of their student enrollments. Altogether, the Yuanzong and the Xuanmiao guan schools admitted more than one third of the total annual enrollment for the whole city of Nanyang during the late Qing period.

Abbot Yao and his monastery's two decades of sustained efforts in building schools in Nanyang earned them recognition from the Qing court and the provincial officials. In 1906, the governor of Henan and the president of the newly established Board of Education (xuebu) in Beijing each memorialized the throne about Yao and his monastery's achievements in promoting the new education in Nanyang. A placard was issued in the name of the reformist but now disgraced and out-of-power Guangxu emperor, and bestowed on the monastery.

23. The Buddhist-run local school weathered the chaos and upheavals of the early Republican era. Despite the state and local warlords'campaigns to restrict and confiscate temple property during the 1920s and 1930s, the primary school continued in operation for the local children until the spring of 1945 when the invading Japanese army in Zhenping disrupted and ended its operation. See Zhenping xian zhi, p. 913-925. 
The placard bearing the imperial inscription, "Quanzhen (Daoism) Proliferates Learning," recognized the monastery's contribution to the Qing local education reforms. Abbot Yao soon had the placard framed on the frontpiece of the scriptorium which housed the precious Daoist Canon, an imperial gift given to abbot Zhang Yuanxuan for his valiance and leadership in the defense of Nanyang during the mid-1860s. Together with the Daoist Canon, the imperial placard was now the visible symbol of the monastery's achievement, reminding each and all visitors to the monastery of its prominence and leadership in promoting the modern popular education in Nanyang. ${ }^{24}$

The Quanzhen monastery also actively participated in the Qing state-initiated programs at promoting agricultural reform by introducing and proliferating modern agricultural knowledge and learning aimed at invigorating local agriculture, trade and economy in the aftermath of the Taiping war. ${ }^{25}$ Zhang Jian (1853-1926) advocated the importance of reforming traditional agriculture and farming practice as a means of strengthening the Qing economy and society. ${ }^{26} \mathrm{As}$ part of their plan for agricultural reforms, Zhang and other reformers also pushed for vocational training and education as a means for disseminating modern farming, industrial and technical knowledge and skills among the rural population. In 1908, the Qing court stipulated for the establishment of the vocational schools (shiye xuetang) along with the new Western schools. In the Nanyang region, a school of sericulture (cansang xuetang) was set up in the northern county of Nanzhao in 1908, followed by similar schools of agriculture and industry (nong gong shiye xuetang), and business (shangye xuetang) in Xichuan, Neixiang, Dengzhou, Zhenping and other counties affiliated with Nanyang throughout the 1910s. At these two-year vocational schools, specialized courses in seraculture, modern agriculture, soil sciences, farming technologies, and business skills were taught, in addition to courses in Chinese, mathematics, geography, history, and arts.

Again even before the advent of these new vocational schools to the Nanyang region, Zhang Jian's proposed agricultural reform had found a ready and enthusiastic supporter in abbot Yao Aiyun. Like Zhang, the Daoist abbot considered dissemination of agricultural knowledge and farming techniques vitally important for strengthening the agrarian society and economy. As the

24. Shi Zongrui, "Xuanmiao guan xiao zhi," p. 111.

25. Wright, The Last Stand of Chinese Conservatism, p. 153-195.

26. For Zhang's life and career as a major late Qing reformer, see Chu, Reformer in Modern China. For his role in the late Qing agricultural reforms, see Xu Jingyu, "Zhang Jian yu Qing mo nongye gaige"; and Wu Chunmei, "Qing mo Xinzheng shiqi.” For a recent study of Zhang's role in shaping modern Chinese society, see Zhang Kaiyuan \& Tian Tong, Zhang Jian yu jindai shehui. 
man in charge of one of the largest landholding temples in Nanyang, Yao took a special interest in promoting the new agricultural learning among the tenants who cultivated the monastery's vast farmlands throughout the Nanyang region. According to Yu Yinlin, abbot Yao carefully studied various new innovative farming methods, from tilling, and irrigation, to fertilization and well-drilling. He taught the monastery's tenant farmers to plant fruit trees in the empty spaces between the farmland plots to help retain moisture and improve the soil conditions. When the fruit trees started to yield fruits, the abbot allowed the tenants to benefit from their sale and collected no extra rents from the crop. As much of the Nanyang plain was crisscrossed by various tributories and streams of the Han and Huai rivers, the farmlands were susceptible to drought in the spring and floods in the summer, resulting in reduced or failed crops. To prevent flooding, Abbot Yao reportedly studied and taught his tenants some ancient tilling techniques which involved furrowing the growing fields and constructing dykes around the farmlands vulnerable to the floods. He also drew up the detailed diagrams which illustrated the methods for drilling irrigation wells, for applying fertilizers to the planted fields, and for raising live-stock, and used them to teach to the tenant farmers. In order to disseminate the new farming techniques, the abbot even paid for the printing and distribution of the diagrams among the tenants and other farmers so that even without veing able to read, they still could learn and implement these farming methods and techniques to forestall the effects of drought or floods, and ensure harvest yearly. ${ }^{27}$

Yao's interest and efforts in educating the monastery's tenants by disseminating more efficient farming methods and techniques among them may have reflected an englightened and entrepreneurial landlord's vision about productivity and profit, but his interest in farming and disseminating agrarian learning and methods is also congruent with the early Quanzhen monastic tradition of self-sufficiency and moral living through agrarian pursuits and ascetics which dated back to the days of its founders during the 12th and 13th centuries. $^{28}$

Yet while abbot Yao's proactive responses to the late Qing state-centered reforms were consistent with the Nanyang Quanzhen monastery's established tradition of defending and serving the Qing state and the Nanyang community, it

27. Yu Yinlin, "Xibei yuan ji," 12.24a.

28. Self-sufficiency through farming and agrarian pursuits was widely practiced among earlier patriarchs of the Quanzhen Daoist sect. See Gai Jianmin, "Quanzhen zi Chen Fu nongxue sixiang kaoshu." On the general relationship beween Daoist cosmology and ethics, and agriculture in China, see Gai Jianmin \& Yuan Mingze, "Daojiao yu Zhongguo chuantong nongye." For early Quanzhen Daoist efforts in agrarian self-sufficiency, see also Xue Youliang, "Qiyun Wang zhenren kai Laoshui ji." 
may have also ironically constituted the cause of his downfall in 1911. After the Republican forces took Nanyang in the winter that year, Yao refused to capitulate to and collaborate with the new Republican regime. When he was executed in early 1912, Yao's alleged crimes, according to contemporary local gazetteers, included "fraternization with the Qing local military and political officials, and lording it over the local community." ${ }^{29}$ Personal acrimination aside, the Yao's execution is symbolic of the deep distrust the Republican intellectuals and activists held toward the traditional religious establishments like the Xuanmiao monastery.

But the Quanzhen monastic activism in promoting and managing local vocational education which Yao pioneered in Nanyang continued and expanded under the new leaders of the Xuanmiao monastery during the Republican era.

\section{Republican State Seizure of Temple Lands and the Daoist Response (1912-1920s)}

Soon after the founding of the Republic in 1912, the Xuanmiao Monastery and the Palace of the Three Primordials played a prominent role in developing a national organization among the Quanzhen Daoists. In the summer of 1912, in response to the initiative by abbot Chen Mingbin of the White Cloud Monastery in Beijing to establish a national Daoist organization, Guo Zhixian (also Yubin,?-?), prior of the Xuanmiao Monastery participated in the initial organizational work for the proposed national Daoist Association. In July that year, Guo, together with abbot Chen and seven other fellow Quanzhen clerics and lay activists representing various Daoist monasteries and lay groups in Beijing, Shanghai, Xi' an, Manchuria, Henan and Hubei went to the Presidential Office of the Republican Government in Beijing, and presented their joint petition to the new government. In this petition, Guo and his fellow Quanzhen clerics demanded that the Republican state extended both recognition and legal protection to Daoism as a legitimate national religion (guojiao). ${ }^{30}$ In August that year, their petition was granted and the first Daoist national association was established, with its headquarters installed at the White Cloud Monastery in the capital. In this first Daoist effort at national organization, Guo Zhixian of the Xuanmiao monastery, and prior Wang Yongchun of the Palace of the Three Primordials joined fellow abbots and priors from fourteen other Quanzhen monasteries, and provided strong leadership and monastic support. Both of the Nanyang

29. For the execution of Yao by the Republican forces, see Wang Baoqing, "Xuanmiao guan zhuchi Yao Aiyun."

30. Zhao Xiangxue, "Daojiao hui shang shu ji” in Daojiao hui diyici bugao. 
Quanzhen monasteries thus became the founding members and the sponsoring institutions of the first national Daoist association in 1912..$^{31}$

But the Quanzhen clerics'vision of Daoism as a national religion for the new republic was not shared by most of the Republican elite who even furthered the late Qing state policies of developing modern education by depriving Daoists of their temple property. The execution of abbot Yao already mirrored the Republican state and intellectuals' hostility and bias toward Daoist monasteries as viable participants in the modernization of the local society in Nanyang. But now this hostility was further intensified by the early Republican political factional strife and the state's practical need for resources to carry out various local reforms. It also led the new Republican regime in Nanyang to adopt far more draconian policies toward the established Buddhist and Daoist monasteries than those adopted by its imperial predecessor. Shortly after coming to power in early 1912, the new Republican authorities in Nanyang began to look beyond the available assets which they inherited from the Qing local administration for new and other possible sources of revenue to fund their modern education and other reform projects in the region. As elsewhere in China, large Buddhist and Daoist monasteries with extensive landholdings offered easy and enticing targets for the expanding early Republican state.

Accumulated over a period of more than two hundred and fifty years since the mid-17th century, the Xuanmiao monastery's landholdings were composed of those under its direct control, and those owned by its affiliated temples and cloisters (xiayuan) located throughout Nanyang. In addition, the monastery also managed some lands placed in its trust by local guilds and temples in Nanyang. While the monastery derived its lion's share of income from its own endowment lands, it also received a significant amount of contribution in the forms of cash and grains from its affiliated temples and cloister. According to the figures revealed in early Republican period sources, the monastery held a total of 77 qing (approximately 7,700 $\mathrm{mu}$ ) farmland as of 1909. Most of the lands were concentrated in the northern and northwestern suburbs of Nanyang. In addition, the Palace of the Three Primordials at the Broad Vista Township owned 20 qing $(2,000 \mathrm{mu})$ farmland. Several other affiliated temples such as the Shrine of the Three Teachings (Sanjiao tang), also known as Master Ye's Cloister (Ye'an) located 15 miles southeast of Nanyang, and the Temple of the Patriarch Master on the Solitude Mount (Dushan Zushi gong) also owned lands.

In addition to the rents generated from their endowment lands, the Xuanmiao monastery and the affiliated temples received considerable income from the

31. See "Daojiao hui xuanyan," and "Daojiao hui shang Yuan dazongtong Guowu zongli shu," ibid. See also Goossaert, Taoists of Peking, p. 74-80. 
donations from pilgrims and local devotees during various temple festivals throughout the year. Lastly, the clerics at the Xuanmiao monastery derived income from their ritual services rendered to the local community, and from the annual temple festivals in honor of their patron deities: Lord Laozi, the Jade Emperor, and the popular Perfected Warrior (Zhenwu), known to the locals as the Patriarch Master (Zushi).

Despite its relative wealth and endowment, the average Quanzhen clerics at the Xuanmiao monastery lived a frugal and simple life. For their ritual services and labor, each of the residents and sojourners was provided free board and room. Information is lacking about the situation of the pre-1900 days. But in the first few decades up to 1938 when the full-fleged War of Resistance accelerated, sojourners and resident clerics at the monastery each received an average monthly stipend (danqian) of 8,000 wen, in addition to their daily room and board. The stipend went to pay for their clothing, footwear, other daily necessities, and occasional good meals. Their daily board at the monastery consisted of three meals of coarse grains (culiang) and vegetables. When there was food shortage, they would subsist daily on two meals of thin gruel and pickles. ${ }^{32}$

With the political turmoil, rising inflation, and depleted monastic resources after the breakout of the Sino-Japanese war in 1937, the Quanzhen clerics at the Nanyang monastery found it increasingly difficult to stretch their meager monthly stipend to cover all their expenses. Many had to make do with old and worn-out clothing and go hungry for days and weeks on end. To survive, many devised ways to take advantage of the free room and board customarily offered at the major Daoist and Buddhist public temples to fellow itinerary Daoist and Buddhist priests. In Nanyang during the late Qing and early Republican era, hungry and impoverished Quanzhen and Buddhist clerics were known to have resorted to rotating their sojourns on a circuit of Daoist and Buddhist major monasteries in the region in order to obtain food and shelter. In a practice known among the locals as "the circular or milling sojourns (mopan dan)," so named to invoke the donkey-drawn circular movement of a turning mill, the starving mendicant Quanzhen and Buddhist clerics would sojourn successively at the five major Daoist and Buddhist monasteries in and around Nanyang, staying the maximum number of days allowed, and then moving onto the next. ${ }^{33}$ But

32. The coarse grains typically refer to sorghum, millet, and corn, as well as the processed flour milled from dried sweet potatoes in Nanyang. See Guanyu Xuanmiao guan, p. 1517, and Shi Zongrui, "Xuanmiao guan xiao zhi," p. 118.

33. Shi Zongrui, ibid., p. 119. The circular circuit consisted of five stops, the first at the Quanzhen Xuanmiao Monastery in Nanyang, the next at the Buddhist Zhunti Monastery in Zhengping about 15 miles west of Nanyang, the third stop at the Buddhist Monastery 
when they exhausted their welcome at all these monasteries, many of them had to turn to begging in the streets to survive. ${ }^{34}$

From 1912 to the late 1930s, the monastery's economic conditions worsened, as its massive landholdings became the primary target of the Republican local government's land expropriation campaigns. By 1934, several major Republican anti-superstition drives, and subsequent local self-government movement (zizhi yundong) in Nanyang had reduced the monastery's landholdings by more than half to just over 3,000 $\mathrm{mu}$. That year, the total acreage of arable land in Nanyang was $2,351,464 m u$. While the total acreage of temple landholdings for the whole Nanyang county was as low as $8,671 \mathrm{mu}$, the total acreage of public or state lands registered under the various Republican local government agencies had shot up to $21,880 \mathrm{mu}$. The sharp increase in the state landholdings in Nanyang was due directly to massive Republican state seizure of monastic property in 1912, 1927, and since. Most of the seized lands were redistributed as public school lands (xuetian) and government lands (gongtian) to support public education and other modern reforms in the the region. ${ }^{35}$

Such was the case of the lands owned by the Medical Sage Shrine (Yisheng ci) near Nanyang's eastern gate. In the year of 1883, the Nanyang Physicians Guild (Yilin huiguan) entrusted the shrine together with its $700 \mathrm{mu}$ of premium farmland to Zhang Yuanxuan, the abbot of the Xuanmiao monastery, for custody and management. The land was initially donated to the shrine by a group of physicians in Nanyang as the permanent source of revenue for the shrine. ${ }^{36} \mathrm{By}$ the late Qing, the shrine's landholding had increased to over $700 \mathrm{mu}$. In 1883 when the medical guild requested that abbot Zhang and his monastery to take over the operations of the shrine, the shrine's endowment lands were also placed under the monastery's control and management.

But when the Nanyang Republican regime began expropriating temple lands for funding the modern schools and other reform projects, it did not make such distinctions. Shortly after 1912, the Republican provisional regime in Nanyang appropriated 2,800 $\mathrm{mu}$ of the lands of the Xuammiao monastery, and allocated them to its education promotion agency (Quanxue suo) to run as the endowment

of the Scarlet Morning Cloud (Danxia si) in Nanzhao about ten miles northeast of Zhengping, the fourth stop at the Quanzhen Palace of the Three Primordials, and the last stop back at the Xuanmiao monastery.

34. Guanyu Xuanmio guan, p. 15-17.

35. Feng Zigang \& Liu Duansheng, Nanyang nongcun shehui diaocha baogao, p. 10-11.

36. The shrine land holdings came from several major donations in early Qing between 1668 and 1710, which totaled to approximately 7,700 zhi bianqian," and "Yisheng ci xianghuo di beiji" in Wang Xinchang \& Tang Minghua (eds.), Yisheng Zhang Zhongjing, p. 124-125. 
lands for all the state-run schools in Nanyang. Of these confiscated lands, about $670 \mathrm{mu}$ were the original endownment lands wrested from the Shrine of the Medical Sage. ${ }^{37}$

The temple land expropriation by the Republican state began in 1912 and continued through the 1920s and 1930s. By 1934, Nanyang's total school endowment lands had swelled to $8,885 \mathrm{mu}$. One third of the total school endowment lands were forcefully taken from the Xuanmiao monastery, leaving the Quanzhen monastery with only 3,000 $\mathrm{mu}$, less than half of its pre-1912 total land holdings. ${ }^{38}$

The effect of the post-1912 Republican land confiscation was immediately visible. The Daoist-run Yuanzong Primary School had to cease operation shortly after the Republican takeover, while the Sancui Primary School at the Broad Vista township struggled to survive on diminished monastic resources in the succeeding years. By late 1920s, the Republican state campaigns against organized religions in Henan reached its apex under the military governorship of Republican warlord Feng Yuxiang (1882-1948). When Feng came to preside over the province for the second time in 1928, he launched a massive and ambitious program to reform the local traditional culture and extend popular education in rural Henan. ${ }^{39}$

In Nanyang and its surrounding counties, many Daoist and Buddhist temples bore the brunt of this new wave of the modern state seizures. The Xuanmiao monastery suffered further deprivation of its temple lands. To counter this menace which threatened their survival, Li Zongyang (?-1938), who became the abbot of the Xuanmiao Monastery after Yao's execution, and two senior Buddhist monks representing the Puti Temple in Zhenping and the Dongda Temple in Nanyang traveled to Nanjing where they petitioned the Republican government to roll back some of General Feng's draconian policies of seizure and occupation in Henan. While in Nanjing, abbot Li Zongyang used his early Revolutionary Alliance (Tongmeng hui) credentials and extensive political and social ties among the Republican government officials, and successfully lobbied the KMT central government to issue a special order of protection (baohu ling) for a list of major Buddhist and Daoist monasteries throughout the Nanyang region. ${ }^{40} \mathrm{Li}$ and his colleagues'action not only protected their respective temples, but it

37. Shui Yinglong, "Chen qing sheng zhengfu di yi ci wen," "Di er ci chengwen" in Wang Xinchang \& Tang Minghua, ibid., p. 132-135.

38. Feng Zigang \& Liu Ruishen, Nanyang nongcun shehui diaocha baogao, p. 10 and 80.

39. Feng first came to dominate Henan as its military governor (dujun) at the end of a major warlord melee in 1922. See Zhang Fang, "Wo suo zhidao de Zhao Ti," and Bai Wentian, "Feng Yuxiang da Zhao Ti."

40. Yin Dejie, Lao Nanyang, p. 185. 
also ensured the continued operations of the local Daoist and Buddhist-funded schools and programs in Nanyang.

Petitioning and persuasion aside, some Daoists may have also resorted to violence in resisting the Republican state encroachment on their temple property. In the late 1920s and early 1930s, Daoist clergy and their monasteries allegedly hired local bandits to intervene ever secretly on their behalf in their ongoing dispute with the Republican state and local government. A case in point was the abduction of Wu Liquan (1892-?). Sometime in December of 1929 at the height of General Feng's drive for temple land seizure, Wu was kidnapped by bandits from his village school in Zhenping county where he taught English, and taken into the mountains in northern Zhenping. The bandits demanded a ransom for his release. But Wu's abduction did not seem to have stemmed exclusively from the bandits'desire for money, but was closely connected to the ongoing dispute over land ownership between the local school officials and the Daoists. Wu was a native of Jun county in northeastern Henan. After graduating from the English Department of the National Advanced Normal College in Wuchang in 1919, Wu began his teaching career at Nanyang Middle School where he taught English. When General Feng Yuxiang launched a province-wide campaign to expand rural education in Henan by expropriating or "smashing temples" (damiao), Wu became an enthusiastic advocate for the program. He recalled years later that his vigorous advocacy for temple expropriation in local villages incurred outrage among the Daoist clerics there, and that these clerics in turn colluded with the local bandits to engineer his abduction. He was held in the mountains for three months, and was released only after the ransom was paid. ${ }^{41}$

\section{The Quanzhen Education as Social Philanthropy in Nanyang (1912-1940s)}

But even with diminishing resources and worsened political and social conditions after 1912, the Xuanmao monastery struggled to stay engaged in its local reform initiatives and commitments. After Yao's execution, the Quanzhen clerics secured the return of abbot Li Zongyang from the Eight Immortals'Palace (Baxian gong) of Xi'an to Nanyang. After a brief controversy involving an interim prior, Li assumed the abbotship at the monastery in 1912 .

41. Wu Liquan, "Peng Yuting." Wu later served as the headmaster of the Catholic missionary Simeon Middle School at Jin'gang in Nanyang between 1938 and 1941. The school was run by the Catholic Diocese of southern Henan headquartered there. See his "Nanyang Jin'gang Ximan zhongxue," and Guo Yimin, "Jin'gang Ximan zhongxue." 
Abbot Li proved just as charismatic and energetic a leader as Yao, but of very different political persuasion. Despite his humble roots which began in Nanyang, Li soon rose through the Quanzhen clerical ranks through his pursuit of ascetics in self-cultivation, and Daoist scriptural studies. During his extensive travels as a young and aspiring cleric, $\mathrm{Li}$ also built extensive personal, cultural, and political ties bout in and outside the Daoist circles with the Qing and later the Republican elite. His yearlong arduous seclusion and meditation in the sacred Mount Song during his youth earned him both renown and friendship among the Confucian literati elite throughout the central plain. While serving as the head of a small Daoist shrine in Xi' an at the height of the Boxer rebellion, Li managed to impress Cixi, the empress dowager and many of her ranking court and local officials with both his upright character and quick wit. But Li was by no means a conservative stalwart. As the anti-Manchu sentiments rose in the post-Boxers years, Li became sympathetic to the underground revolutionary cause, and befriended many antiManchu intellectuals and activists. He later joined the Revolutionary Alliance, the arch-nemisis of the Qing empire, and used his wide political ties among the Qing officialdom and his shrine in Xi'an to provide cover for the anti-Qing revolutionaries throughout the northwestern regions. But most of all, Li proved to be an energetic and resourceful Daoist leader whose achievements and exciting reforms as a monastic leader became widespread among the Daoist circles. So shortly after abbot Yao was executed by the Republican forces in early 1912, the Quanzhen clerics at the Nanyang's Xuanmiao monastery decided to invite Li back to Nanyang to head their monastery. ${ }^{42}$

Li accepted the invitation, and returned to Nanyang in 1912. His extensive contacts and political experience prepared him well for managing the much larger Nanyang monastery at a time of fast changing social and political conditions in the early Republican era. Faced with diminished temple resources and the loss of powerful local patrons, Li still managed to keep his monastery's commitment to several local reform programs, and sustained the monastery's presence in areas of public education, social welfare, and vocational training in Nanyang for decades after 1912 .

In 1927, after the Xuanmiao school was forced out of operation for over fifteen years, abbot Li reopened it in the renovated Martial Marquis Shrine (Wuhou ci) located in the east wing of the Xuanmiao Monastery. The re-established Shaohuai School (Shaohuai xiaoxue), like its predecessor, was divided into the junior and the senior departments. It admitted a total of 100 students in the first year. There, it continued in operation on the funds set aside from the monastery's

42. Cao Tianduo, Hansan zi Li Zongyang daoxing bei, transcribed stele inscription in my possession. 
annual rents generated from its dwindling landholdings, ever after Li had left the monastery in 1929. Between May of 1932 and May of 1933, the Shaohuai Primary School managed to secure some funding support from the Republican general Liu Zhenhua (1883-1956) who had set up his headquarters inside the monastery. As part of his overall plan for promoting local education, commerce, and culture, the Republican general allocated funds from confiscated assets of the local hegemons and "unruly" merchants for the renovation of the temple buildings which housed the school, and for the procurement of instructional equipments for the monastery school. ${ }^{43}$ The circumstances of what prompted the Republican strongman to provide support to the monastery's school remain unclear. But the support from the Republican general did not last.

In any event, the Xuanmiao monastery's activism in promoting new schools in Nanyang met a devasting setback in the summer of 1938, when the Japanese air raids over Nanyang destroyed several of the Xuanmiao Monastery's major halls and shrines, including the Martial Marquis Shrine which housed the Shaohuai school. But the Daoist-funded primary school persisted, despite greatly diminished resources and worsend political and economic conditions of the war, until 1945 when the city of Nanyang fell to a brief occupation by the Japanese troops. ${ }^{44}$

\section{The Orphanage and the Vocational Training Workshop}

Another important social philanthropic and educational institution which the monastery provided to the public was the orphanage founded by abbot Li. The worsened social, political and ecological conditions aggravated by wars, banditry, and the frequent droughts and flooding in the early Republican decades gave rise to the widespread problem of orphans and abandoned children in the Nanyang area. ${ }^{45}$ Pre-occupied with gaining or keeping power and control of the strategic region, the fast-alternating warlord regimes and Republican governments in Nanyang had neither the attention, nor the resources to deal with the problem.

43. The warlord general's brief reign in Nanyang, including his support for educational and cultural projects has left some impression on the local elite, especially Mr. Shui Puci who came from an established literati family in Nanyang and taught at local schools all his life. See Shui Puci, "Liu Zhenhua zai Nanyang."

44. Shi Zongrui, "Xuanmiao guan xiao zhi," p. 122.

45. Between 1909 and 1919 , there were at least four major crop failures due to natural calamities of draughts, floods, or hails in Nanyang. Some of the crop failures were also accompanied by outbreaks of plague. 
Abbot Li and his monastery took a leading role in organizing care for the abandoned or orphaned children. In 1924, the Xuanmiao monastery set up an orphanage adjacent to the Red Cross Hospital in the east wing of the monastery. The orphanage admitted nearly 90 orphans, and abandoned, impoverished and homeless children from Nanyang. The minimum admitting age for the orphans was seven. They were expected to leave the orphanage by the age of eighteen. During the drought, the Xuanmiao monastery collaborated with the national relief organizations such as the Shanghai Famine Relief (Shanghai jiusheng hui) to provide care for the famine-stricken children in Nanyang. The 1929 famine in Nanyang added several dozens more orphans and and homeless children to the orphanage, which had to hire two additional full-time caregivers to cook, clean, wash, and care for its now expanded population.

Aside from providing physical care, the monastery's orphanage also tried to educate the children. After abbot Li reestablished the Shaohuai School in the Martial Marquis Shrine at the Xuanmiao monastery in 1927, all school-age orphans were admitted there to take classes. Abbot Li and his fellow clerics also devised various educational paths for the orphans. Those who excelled in learning could go onto middle schools in Nanyang. Others who did not succeed academically would learn various crafts and skills at the vocational workshops so that they could support themselves after they reached the age of eighteen. ${ }^{46}$

These vocational workshops were also an important component of the Quanzhen Daoist activism in local modern education in Nanyang, and they were set up and operated in close connection with the local markets and economy. Since the Ming and early Qing, Nanyang had remained a major center of commodity trade and distribution on the upper stretch of the Han River valley. While the completion and operation of the Peking-Hankou Railway line (Ping Han xian) and other new transportation routes diverted much of the trade and commercial traffic from Nanyang, its status as a regional trade and distribution center in the upper Han River valley continued unabated. ${ }^{47}$ Much of the westbound flow of trade goods from Shanghai and Hankou to the upper reaches of the Han River valley and beyond continued to go through Nanyang. So the downtown Nanyang streets and the surrounding townships such as Shiqiao, Anhao, Liaohe, Wadian, and Shedian along the tributaries of the Han River remained vital transit points and markets which handled the exports of raw cotton, handmade clothes, grains, tobacco, oils, and animal hides and furs from Shaanxi, Shanxi, eastern Sichuan and western Henan provinces, and the imports of daily consumer goods such

46. Shi Zongrui, "Xuanmiao guan xiao zhi," p. 122-123.

47. For the early modern Chinese railway construction and service, see Li Guoqi, Zhongguo zaoqi de tielu jingying, Nan'gang: Academia Sinica, 1961. 
as paper, matches, lighting oils, and machine-woven textiles from downstream trade centers like Hankou and Shanghai.

The active commerce at these Nanyang market towns produced a constant demand for craftsmen and workers skilled in textile-making, carpentry, and jadework. Since the late 19th century, Qing state and local officials had tried to integrate the need to meet this rising demand as part of their overall plan to promote trade and industry in order to revitalize and modernize the national and local economy after the Taiping suppression. In 1907, the Nanyang country magistrate set up the Nanyang Crafts Training Center (Nanyang xiyi suo) to train the county prison inmates in silk-making. By 1915 this former Qing local crafttraining center had been expanded into a large model workshop for vocational training (Nanyang quan gong chang) in paper-making, ironwork, woodwork, and quarry-work. ${ }^{48}$

Abbot Li and his Xuanmiao monastery's interest in developing vocational training programs for the orphans under their care thus reflected both the modernizing ambitions of the Qing and the early Republican state, and the practical economic orientations and demands of the local markets in Nanyang.

In 1927 when abbot Li reestablished the Shaohuai School, he also opened a special training workshop. The vocational training center at the monastery combined its mission in social philanthropy and its interest in popular education, and enrolled primarily the homeless children and orphans from its orphanage, as well as young apprentices from the local shops and businesses in Nanyang. At the training workshop, trainees were taught four major craftsmanships that were in high demand throughout the Nanyang region. These were textilemaking, woodwork, jadesmithing, and shoemaking. While the primary goal of the workshop remained the training of the orphans in various trade skills and craftsmanship, it also aimed at self-reliance through the sales of the products the trainees produced at the workshop.

The operations of the workshop received an unexpected boost from the outbreak of the Sino-Japanese war in 1937. With the Peking-Hankou Railway, the Longhai Railway (Long Hai xian) and the other major land routes of trade and transportation either falling to the Japanese control, or frequently disrupted by war, Nanyang's relative isolation now became an advantage. As the cities of Kaifeng, Zhengzhou, and Wuhan fell, Nanyang became a major alternative trade and transportation nexus of materials and commodities for the Chinese resistance forces and the Republican-controled regions in western Henan, and beyond. Indeed, as the war waged on from the summer of 1937, Nanyang not only regained its old status as a trade town and market in the upper Han

48. Zhou Dianjun, "Suotan Nanyang shangye," p. 101-122. 
River valley, but it also became the new transit center and supply base for Chinese resistance troops for the whole North and Central China regions. As the regular supplies of machine-made clothes and other daily necessities from the coastal urban centers were cut off by the Japanese forces during the war, locally produced clothes (tumianbu) and goods from Nanyang and other free regions also became increasingly in demand by the resistance forces and the civilians in the Republican government controlled free zones. ${ }^{49}$ Several Republican army corps and their headquarters, and supply requisition units stationed in and around Nanyang region helped fuel the demand for both local goods and skilled labor.

Such demand in turn helped keep the Xuanmiao monastery's training workshop in operation, especially during the early phase of the war. At the workshop, textile making became the most popular of the four skills among the trainees. The workshop produced several products such as hand-towels and special-weave cloths (renzini and pingmianbu) which were in high demand. In late 1938, the operation of the training workshop wasdisrupted by Japanese airraids, as the buildings in the monastery's east wing which housed workshop was damaged the bombing. While it managed to resume operation a year and half later in 1940, the workshop was not able to fully regain its early momentum in the very competitive market. Due to a convergence of factors of long production cycle, uneven product quality, and frequent Japanese air-raids, the workshop had to close not long after $1940 .{ }^{50}$

\section{Last Efforts: The Homeless Children Training Center (1945-1949)}

The monastic compound had since the early 1920s been frequently occupied by various armies as their barracks and headquarters. At the height of the war, the monastery itself became a major target of Japanese air-bombing raids over NanyangIn the fall of 1937, the monastery suffered a major destruction during the Japanese air-raids. Several of the major halls were badly damaged, and the monastery's gate-tower and its entrance shrine were completely razed to the ground. In addition to the air-raids, the monastery was soon commandeered by the Republican resistance forces as their command headquarters during the war. In the last year of the war, it was briefly occupied by the Japanese army. As a result, much of the monastery's operations in local education and philanthropy were either disrupted and completely haulted.

Only beginning from 1945 did the Xuanmiao monastery begin to recover slowly from the devastating effects of the war. But by then, the monastery

49. Liang Zhesheng, "Nanyang tumianbu."

50. Shi Zongrui, "Xuanmiao guan xiao zhi," p. 123. 
had lost much of its former wealth. By 1946, a portion of the Xuanmiao monastery's remaining endowment lands were reorganized and managed by the Nanyang Daoist Association (Nanyang xian Daojiao hui) and its affiliated Plum Creek Cooperative Farm (Meixi hezuo nongchang). It remains unclear as to exactly when the Nanyang Daoist Association first came into existence, but there is no doubt that the Association was dominated by the senior clerics from the Xuanmiao monastery, and their its local elite followers. Given the early involvmernt of the Xuanmiao monastery in the first national Daoist organization in 1912, it is conceivable that the Nanyang Daoist association may have been formed fairly early as a local chapter of the national association, and remained activeever since. In 1946, the Daoist farm was set up with detailed bylaws, rules of operations, and accounting method. Its headquarters was located in the eastern wing of the Xuanmiao monastery, with much of its farming operations and facilities located at the Daguanzhuang, a village located west of the Xuanmiao monastery and in the northwestern suburbs of Nanyang.

Between 1946 and 1949, the cooperative farm became one of the most visible Daoist institutions that continued the Quanzhen monastic tradition of social and medical philanthropy and free education for the public, especially the war-displaced poor and homeless children in Nanyang. Under the worsening conditions of the post-war Nanyang, the Daoist farm operated a free medical clinic and apothecary (Meixi nongchang yiyao shishe suo), and a vocational training center for the poor and homeless children (Meixi nongchang nantong xunlian ban). The medical clinic and apothecary there also revived the functions of the earlier Red-Cross clinic, and even operated from the same buildings donated by the Xuanmian monastery in its east wing.

The cooperative farm was initially set up with temple lands donated by the Xuanmiao monastery along a small river known as the Plum Creek (Meixi) which flows around the western outer perimeters of the monastery southward before draining into the White River to the south of Nanyang. The Xuanmiao monastery's interest in agriculture was first documented with abbot Yao Aiyun during his tenure from 1880s to 1911. Yao was said to have taken an active interest in disseminating and implementing the new agricultural technologies among the monastery's tenant farmers. He paid for the printing and circulation of tracts which illustrated the modern irrigation, well-drilling, fertilization, cross-cultivations in Nanyang..$^{51}$ This early Daoist interest in agriculture as the stock of local society and the monastic life was continued at the Xuanmiao

51. Yu Yinlin, "Xibei yuan ji." Similar Daoist experiments were also pursued by Daoist clerics at Daoist monasteries on Mt. Qingcheng in Sichuan during the late Qing and early Republican periods. See Li Yuchuan, "Peng Chunxian daozhang." 
Monastery. Immediately after the anti-Japanese war ended in 1945, abbot Nie Xiaoxia (fl.1930s-1950s), prior Wei Shaopo and a group of prominent local businessmen, intellectuals, and educators with close ties to the Xuanmiao Monastery joined hands in establishing the Plum Creek Cooperative. The primary mission of the agricultural cooperative farm as stated in its charter was: 1) to develop cooperative farming (fazhan nongye hezuo); 2) to implement collective production (shixing jiti shengchan); and 3) to promote and disseminate select agricultural crops and seeds (tuiguang youliang pinzhong) in Nanyang. The new farm operated under the direction of a board composed of Nanyang's leading intellectuals and entrepreneurs. The chairman of the board was Yang Heting (1877-1962), a prominent local literatus, public educator, and a devout Daoist lay activist with close personal and family ties to the Xuanmiao monastery. ${ }^{52}$ Both the Quanzhen clerics and the lay activists on the board saw public services as an important legacy of the monastery and a much needed response to the social and economic problems of the post-war Nanyang society. ${ }^{53}$

In September of 1946, the Nanyang Daoist Association petitioned the Nationalist municipal government in Nanyang for permission to set up a special training center for the homeless children at its farm. In its memo to the local government, the Association stated that the mission of the center was to gather the homeless and refugee children who had lost their opportunity for schooling due to the war, loss of parents, or impoverishment, and to provide them with food, shelter, and basic education and vocational skills at the Daoist farm. The center was established at the Daoist farm located in the Daguan village in northwestern suburbs of the city. Several dozens of the homeless children were enrolled at the center. Instruction began in October of 1946, and the training center appeared to have stayed in operation until 1949 when Nanyang fell under Communist control.

Though details of how the center operated remain to be fully investigated, the Daoist training center for the homeless children represented a major financial commitment for the Nanyang Daoist Association. Judging from the speed of the approval of the Association's initial memorial for the center, it is tempting to suspect that Nanyang's Nationalist municipal government must have seen the problem of the homeless children as a substantial drain on its coffer, and was thus willing to embrace the Daoist involvement in urban social relief and welfare programs. But the Daoists were no dummies in undertaking the philanthropic and educational programs. Shortly after launching the training center in the fall of 1946, the Daoist Association filed a petition to request the Nanyang municipal

52. For Yang's life and career, see Bi Yueming, "Xinhai geming zai Nanyang"; Qin Jun, "Yang Heting shilue"; and Yang Tingbin, "Ji Nanyang Yangshi jiazu."

53. "Nanyang Meixi cun hezuo nongchang zuzhi zhangcheng." 
government to grant tax and levee immunity to the Daoist farm. They cited as the reasons for such immunity the costs for operating the training center at its farm, and succeeded in obtaining the immunity from the municipal authorities. ${ }^{54}$

\section{Conclusion}

This preliminary investigation reveals that far from being an obstacle or a victim, Quanzhen Daoism played an active role in shaping the course and contours of the modern educational reforms in Nanyang from the late Qing era to the early Republican period. First, contrary to the conventional view, the Quanzhen Daoist activism in the public arenas of educational, agricultural and social welfare reforms should not be construed simply as a state-coerced and involuntary institutional reaction, or narrowly as a cynical preemptive response to the threat of state expropriation of temple property. Rather, as the case in Nanyang shows, the Xuanmiao monastic activism in late Qing and early Republican era reforms conforms to a long-established tradition of the Quanzhen clerical and monastic collaboration with both the state and the local society. Such tradition began with the monastery's cooperation with the Qing state in the reconstruction of Nanyang at the time of the Manchu conquest of China during the mid-17th century. Evidences suggest that the Quanzhen clerical leadership and monastic efforts in the early modern reforms in Nanyang seem to have continued this long-running tradition of collaborating with the state and the local community. Though we are privy to the inner motives that inspired and drove the Daoist activism in modern education, neither fear or cynicism alone seem adequate for fully understanding the persistent and sustained pattern of the Quanzhen monastic efforts in modern education. All evidences so far reveals that the Nanyang Quanzhen clerics seem to have been driven forces more powerful and longlasting than fear and cynicism. Could it be that they were inspired by a shared sense of the early Quanzhen tradition in pubic philanthropy and service as evidenced in the hagiographies of early Quanzhen patriarchs? Or could it be that their activism was motived by their understanding of their own monastery's historical relationship to and responsibility for the local community over several hundred years? Until the 1960s, many of the Nanyang monastery's steles attesting to its record in deep and moral commitment to both the imperial state and the local community stood conspicuously in a reserved quarter in the westwing of the monastery. Indeed, the heroics of how the Quanzhen monastery and its clerics saved Nanyang and its population in war and famine of the old have persisted in the popular imagination and local lore today. It is therefore

54. "Benchang zhaoshou nanmin ertong xulian ban chengwen." 
hard to imagine that the Daoist monastic leaders Yao Aiyun and Li Zongyang and their fellow clerics would have pursued their activism in disregard to such a rich legacy, one that has in the first place provided them with both authority and authenticity. In all events, the Xuanmiao monastic activism in late Qing and early Republican reforms represents an extension of this early tradition. It also demonstrates Nanyang Quanzhen Daoists'ability and willingness to adapt to the fast-changing social and political realities of the modern period.

Second, the authority and ability of the Xuanmiao monastery in carrying out the modern education reforms in Nanyang derived from a convergence of several factors: the monastery's moral authority, its organizational strength, material resources, and its capable and resourceful clerics. These factors had evolved over time and were deeply rooted the monastery's history and embedded in the local Nanyang community. Aside from its moral authority, the Xuanmiao monastery's extensive landholdings, though incrementally diminished since the late Qing, provided the economic foundation and means for initiating and sustaining the various monastic projects in modern education, social philanthropy, and vocational training. In Nanyang where due to constant warfare and depopulation, local lineages were historically relatively weak and large landlords were few in numbers. It is not surprising that large and wealthy religious institutions such as the Quanzhen Xuanmiao monastery were often the dominant players in local society. In this case, the experience of the Xuanmiao monastery during the late Qing state expropriation of temple lands for education may indeed differ from the fate of Quanzhen institutions in other places. Whereas the Quanzhen order and the local Daoist temples in other places like Sichuan suffered near total devastation during the late Qing state expansion, ${ }^{55}$ the Xuanmiao monastery in Nanyang was able to survive and actively participate in the process of local modernization.

Lastly, I hope that this preliminary inquiry can also re-open our examination of and reflection on the role of traditional religions in the process of China's evolving history of modernization and modernity. In investigating and understanding the early emergence and development of China's modern education, most historians have so far only tended to identify the modernizing Qing and Republican states, the Western missionaries, the Western-educated Chinese intellectual elite, and increasingly the traditional literati and commercial guilds as the main designers, movers and shakers. But few have paid attention to indigenous religions as important actors in the early phase of that process. As a result, while foreign religious institutions and individuals, with a few exceptions,

55. Guo Wu describes the total devastations of the Quanzhen temples during the late Qing and early Republican period. See his “Jinxiandai Sichuan Quanzhen dao,” p. 12-22. 
tend to be portrayed as harbingers, advocates, and pioneers of China's modern education, traditional religions are often seen either as outright obstructionist, or as hopelessly irrelevant to that process. Still another tendency among the historians of the subject is to perceive the involvement of the traditional indingenous institutions, especially the Buddhist and Daoist monasteries as being motivated by their private and selfish interests. The case of the Xuanmiao monastic activism in the early phase of modern educational reform in Nanyang is sufficient cause for questioning and rethinking the validity of these tendencies in the present scholarship.

As shown here, powerful and resourceful religious institutions could and did play important roles in the process of China's modernization in some local communities. Their involvement in establishing new schools and social philanthropic projects was driven not merely by their instincts for survival in times of great social and political change, but was also inspired by their own history of collaboration with the state, and by their tradition of commitment and service to the local community. Yet, unfortunately, modern expansionist states especially the Republican authorities tended to view such monastic activism as competitive and potentially disruptive, and thus repeatedly undermined it by depriving its economic resources and political influence in the public arena. So ultimately, it was not the Daoist ignorance or its lack of public interest and innovation, but rather the Republican elite's vision of a totalistic state and its intolerance that eclipsed and ultimately excluded the remarkable Quanzhen Daoist activism from the spheres of education, social welfare, and other public arenas during the early 20th century China, until the late 1950s when such gradual process of deprivation and exclusion reached its climax with the closure of the Xuanmiao monastery under the Communist rule in Nanyang. The Quanzhen monastery would remain closed until early 1980 s when it regained another life in the now reconfigured and continuously unfolding new religious landscape of the post-Mao China, a story yet to be told elsewhere. 


\section{Appendix 1. Primary schools in late Qing Nanyang city (清末南陽小學堂一覽表)}

\begin{tabular}{|c|c|c|c|c|c|c|c|}
\hline $\begin{array}{l}\text { 學堂名稱 } \\
\text { School names }\end{array}$ & $\begin{array}{l}\text { 創建時間 } \\
\text { Founding date }\end{array}$ & $\begin{array}{l}\text { 地址 } \\
\text { Location }\end{array}$ & $\begin{array}{l}\text { 堂長 } \\
\text { Schoolmaster }\end{array}$ & $\begin{array}{l}\text { 教師數 } \\
\text { No. of } \\
\text { Faculty }\end{array}$ & $\begin{array}{l}\text { 公私立 } \\
\text { Public or } \\
\text { Private }\end{array}$ & $\begin{array}{l}\text { 學生數 } \\
\text { No. of } \\
\text { enrolled } \\
\text { students }\end{array}$ & $\begin{array}{l}\text { 歲支銀 } \\
\text { Annual } \\
\text { budget } \\
\text { (silver taels) }\end{array}$ \\
\hline $\begin{array}{l}\text { 崇正高等小 } \\
\text { 學堂 } \\
\text { Chongzheng } \\
\text { Senior } \\
\text { Elementary } \\
\text { School }\end{array}$ & $\begin{array}{l}\text { 光緒二十八年 } \\
1902\end{array}$ & $\begin{array}{l}\text { 崇正書院 } \\
\text { Former } \\
\text { Chongzhen } \\
\text { Academy }\end{array}$ & $\begin{array}{l}\text { 任朱學 } \\
\text { Ren Zhuxue }\end{array}$ & 8 & $\begin{array}{l}\text { 公 } \\
\text { Public }\end{array}$ & 60 & 1600 兩 \\
\hline $\begin{array}{l}\text { 玄妙觀兩等 } \\
\text { 小學堂* } \\
\text { Xuanmiao } \\
\text { Monastery } \\
\text { Primary } \\
\text { School }\end{array}$ & $\begin{array}{l}\text { 光緒三十一年 } \\
\text { 十月 } \\
\text { Oct, } 1905\end{array}$ & $\begin{array}{l}\text { 北關大街 } \\
\text { Main Street } \\
\text { Northgate }\end{array}$ & $\begin{array}{l}\text { 王衍賓 } \\
\text { Wang } \\
\text { Xianbin }\end{array}$ & 8 & $\begin{array}{l}\text { 私 } \\
\text { Private }\end{array}$ & 117 & 600 兩 \\
\hline $\begin{array}{l}\text { 勸忠兩等小 } \\
\text { 學堂 } \\
\text { Quanzhong } \\
\text { Primary } \\
\text { School } \\
\end{array}$ & $\begin{array}{l}\text { 光緒三十一年 } \\
\text { 十月 } \\
\text { Oct, } 1905\end{array}$ & $\begin{array}{l}\text { 西關二忠祠 } \\
\text { Dual } \\
\text { Loyalty } \\
\text { Shrine } \\
\text { Westgate } \\
\end{array}$ & $\begin{array}{l}\text { 張友珍 } \\
\text { Zhang } \\
\text { Youzhem }\end{array}$ & 10 & $\begin{array}{l}\text { 公 } \\
\text { Public }\end{array}$ & 65 & 1000 兩 \\
\hline $\begin{array}{l}\text { 元宗兩等小 } \\
\text { 學堂* } \\
\text { Yuanzong } \\
\text { Primary } \\
\text { School }\end{array}$ & $\begin{array}{l}\text { 光緒三十二年 } \\
\text { 正月 } \\
\text { Feb, } 1906\end{array}$ & $\begin{array}{l}\text { 北關 } \\
\text { Northgate }\end{array}$ & $\begin{array}{l}\text { 姬永泰 } \\
\text { Ji Yongtai }\end{array}$ & 4 & $\begin{array}{l}\text { 私 } \\
\text { Private }\end{array}$ & 96 & 400 兩 \\
\hline $\begin{array}{l}\text { 模範初等小 } \\
\text { 學堂 } \\
\text { Nanyang } \\
\text { Model Junior } \\
\text { School } \\
\end{array}$ & $\begin{array}{l}\text { 光緒三十四年 } \\
\text { 二月 } \\
\text { Feb, } 1908\end{array}$ & $\begin{array}{l}\text { 勸學所內 } \\
\text { Education } \\
\text { Promotion } \\
\text { Office }\end{array}$ & $\begin{array}{l}\text { 張中孚 } \\
\text { Zhang } \\
\text { Zhongfu }\end{array}$ & 2 & $\begin{array}{l}\text { 公 } \\
\text { Public }\end{array}$ & 33 & \\
\hline $\begin{array}{l}\text { 淯陽小學堂 } \\
\text { Yuyang } \\
\text { Primary } \\
\text { School }\end{array}$ & $\begin{array}{l}\text { 宣統二年二月 } \\
\text { Feb, } 1910\end{array}$ & $\begin{array}{l}\text { 南關 } \\
\text { Southgate }\end{array}$ & $?$ & 6 & $\begin{array}{l}\text { 公 } \\
\text { Public }\end{array}$ & 52 & $\begin{array}{l}\text { 寨局款 } \\
\text { 撥付 }\end{array}$ \\
\hline $\begin{array}{l}\text { 臥佛小學堂 } \\
\text { Wofo } \\
\text { Primary } \\
\text { School } \\
\end{array}$ & $\begin{array}{l}\text { 宣統三年 } \\
1911\end{array}$ & $\begin{array}{l}\text { 臥佛寺 } \\
\text { Reclining } \\
\text { Buddha } \\
\text { Temple } \\
\end{array}$ & $?$ & 8 & $\begin{array}{l}\text { 私 } \\
\text { Private }\end{array}$ & 60 & 100 兩 \\
\hline $\begin{array}{l}\text { 商業初等小 } \\
\text { 學堂 } \\
\text { Commerce } \\
\text { Junior School }\end{array}$ & $\begin{array}{l}\text { 宣統三年 } \\
1911\end{array}$ & $\begin{array}{l}\text { 老鹽店 } \\
\text { Old Salt } \\
\text { Shop }\end{array}$ & $?$ & 9 & $\begin{array}{l}\text { 私 } \\
\text { Private }\end{array}$ & 54 & $\begin{array}{l}\text { 陽局商會 } \\
\text { 款200 兩 }\end{array}$ \\
\hline $\begin{array}{l}\text { 兩等女子小 } \\
\text { 學堂 } \\
\text { Girls'Primary } \\
\text { School }\end{array}$ & $\begin{array}{l}\text { 宣統三年 } \\
1911\end{array}$ & $\begin{array}{l}\text { 府學西 } \\
\text { West of the } \\
\text { Prefectural } \\
\text { Academy }\end{array}$ & $?$ & 8 & $\begin{array}{l}\text { 私 } \\
\text { Private }\end{array}$ & 80 & 600 兩 \\
\hline
\end{tabular}

Those marked by "*” "indicate they were founded and run by the Xuanmiao monastery. (Based on Shi Zongrui, "Xuanmiao guan xiao zhi.") 


\section{BiBLIOGRAPHY}

Ayers William, Chang Chih-tung and Educational Reform in China, Cambridge, Harvard University Press, 1971.

BAI Limin, Shaping the Ideal Child: Children and Their Primers in Late Imperial China, Hong Kong, Chinese University Press, 2005.

BAI Wentian 白文田, “Feng Yuxiang da Zhao Ti de jianwen” 馮玉祥打趙惕的見聞, Nanyang wenshi zhiliao 南陽文史資料 31, 1989, p. 171-173.

Bastid-BruguiÈre Marianne, Aspects de la réforme de l'enseignement en Chine au début de $\mathrm{XX}^{e}$ siècle, d'après les écrits de Zhang Jian, La Haye, Mouton, 1971.

“Benchang zhaoshou nanmin ertong xulian ban chengwen”本場招收難民兒童訓練 班呈文, in “Nanyang Daojiao hui sili Meixi nongchang chengwen”南陽道教會 私立梅溪農場呈文, Nanyang Municipal Archive file, Min 5, File 7, p. 21-22.

BI Yueming畢躍明, “Xinhai geming zai Nanyang” 辛亥革命在南陽, Nandu xuetan 南 都學壇 4, 1997, p. 118-120.

BiggerstafF Knight, The Earliest Modern Government Schools in China, Ithaca, Cornell University Press, 1961.

CH'EN Ch'ing-chih (CHEN Qingzhi) 陳青之, Zhongguo jiaoyu shi 中國教育史, Taipei, Commercial Press, 1966.

Chu Samuel C., Reformer in Modern China: Chang Chien, 1853-1926, New York, Columbia University Press, 1965.

Daojiao hui diyici bugao 道教會第一次佈告, Beijing Baiyun guan Zhongyang Daojiao hui zong jiguan bu 北京白雲觀中央道教會總機關部, 1912.

Edmunds Keyser, Modern Education in China, Washington, Govt. Print Office, 1919.

FENG Zigang 馮子崗 \& LiU Duansheng 劉端生, Nanyang nongcun shehui diaocha baogao 南陽農村社會調查報告, Shanghai, Liming shuju, 1934.

GoossaerT Vincent, “1898 : The Beginning of the End for Chinese Religion?”, Journal of Asian Studies 65 (2), 2006, p. 307-35.

- - The Taoists of Peking, 1800-1949. A Social History of Urban Clerics, Cambridge (Mass.), Harvard University Asia Center, 2007.

Guanyu Xuanmiao guan 關於玄妙觀, Anonymous, Nanyang, internal publication, n.d. (ca. 1972).

Guo Wu郭武, “Jinxiandai Sichuan Quanzhen dao fazhang gailun” 近現代四川全真 道發展概論, Paper given at the International Symposium “Quanzhen Daoism in Modern Chinese Society and Culture", UC Berkeley, 2007.

Guo Yimin 郭益民, “Wo suo zhidao de Nanyang Jin'gang Ximan zhongxue” 我所知道 的南陽靳崗西滿中學, Henan wenshi ziliao 河南文史資料 14, 1985,p. 168-175.

Hsiao Theodore Ên-chêng, The History of Modern Education in China, Shanghai, Commercial press, 1935.

Iсніко Chūzō, "Educational Reform", from his "Political and Institutional Reforms, 1901-1911" in John King FaIRBAnK and K.C. Liu (eds.), The Cambridge History of China, vol. 11: Late Ch'ing, 1800-1911, Pt. 2, Cambridge, Cambridge University Press, 1980, p. 375-416.

Igarashi Kenryu, Dōkyō sōrin Taishingū shi, Tōkyō, Kokusho Kankōkai, Shōwa 61, 1986. 
JIN Liang 金梁 (comp.), Guang Xuan liezhuan 光宣列傳, reprint edition in W ANG Youli 王有立 (ed.), Zhonghua wenshi congshu 中華文史叢書, ser. 10, Taipei, Huawen shuju, 1969, p. 215-217.

KUI Futai達富太 \& BAI Wanxian白萬獻, “Xuanmiao guan hua gu”玄妙觀話古, in Nanyang jixing 南陽記行, Beijing, Wuzhou chuanbo chubanshe, 2000, p. 131132.

Li Enhan李恩涵, “Tongzhi nianjian Shaan-Gan Huimin shibian zhong de zhuyao zhanyi 同治年間陝甘回民事變中的主要戰役,” in Zhongyang yanjiuyuan jindaishi yanjiusuo jikan 中央研究院近代史研究所集刊 7, 1978, p. 95-124.

Li Guoqi 李國祁, Zhongguo zaoqi de tielu jingying 中國早期的鐵路經營, Taipei, Institute of Modern History, Academia Sinica, 1961.

Li Li'an 李理安, Changchun guan zhi 長春觀志, Wuchang, privately printed, ca.1936.

LI Yuandu 李元度, “Duo zhongyong gong bie zhuan” 多忠勇公別傳, in MiaO Quansun 繆全荪 (comp.), Xu beizhuan ji 續碑傳集, Taipei, Wenhai chubanshe, 67: 5b-12a.

LI Yuchuan李豫川, “Peng Chunxian daozhang shengping mantan”彭椿仙道長生平漫 談, Zhongguo daojiao 中國道教 4, 1994, p. 26-29.

LIANG Zhesheng 梁哲生, “Kangri shiqi de Nanyang tumianbu” 抗日時期的南陽土棉 布, Nanyang xian wenshi ziliao 南陽縣文史資料 3, 1989, p. 116-118.

Lin Zuojia 林作嘉, “Qingmo Minchu miaochan xingxue zhi yanjiu” 清末民初廟產興 學之研究, M. A. thesis, Taichung, Tunghai University, 2000.

“Lishi shang Nanyang xian de shui han zaihai” 歷史上南陽縣的水旱災害, Nanyang xian wenshi ziliao 南陽縣文史資料 7, 1993,p. 15-19.

Liu Chengyou 劉成有, “Luelun miaochan xingxue jiqi dui Daojiao de yingxiang” 略 論廟產興學及其對道教的影響, text online: http://www.taoist.org.cn/webfront/ webfront_viewContents. cgi?id=1725, accessed in January, 2010.

Liu Xun, "General Zhang Buries the Bones: Early Qing Reconstruction and Quanzhen Daoist Collaboration in the Mid-17th Century Nanyang," Late Imperial China 27 (2), 2006, p. 67-98.

_ - , "In Defense of the City and the Polity: The Xuanmiao Monastery and the Qing Anti-Taiping Campaigns in Mid-19th Century Nanyang," T'oung Pao 95, 2009, p. 297-333.

“Nanyang Meixi cun hezuo nongchang zuzhi zhangcheng” 南陽梅溪村合作農場組織 章程, Nanyang Municipal Archive file: Min 5, File 7, p. 35-43.

Nanyang minzu zongjiao zhi 南陽民族宗教志, Nanyang, internal circulation, no date available.

Nanyang shizhi 南陽市志, Zhengzhou, Henan renmin chubanshe, 1989.

PAN Shoulian潘守廉 (comp.), Nanyang xianzhi 南陽縣志, 1904, reprinted edition in Zhongguo fangzhi congshu: Huabei defang 中國方誌叢書一一華北地方, 457, Taipei, Chengwen chubanshe, 1976.

QIN Jun 秦俊, “Nanyang Xinhai geming xianqu Yang Heting shilue 南陽辛亥革命先 驅楊鶴汀事略,” Nanyang wenshi ziliao 南陽文史資料 2, 1986, p. 57-60.

SHI Zongrui 石宗瑞, “Xuanmiao guan xiao zhi 玄妙觀小志,” Nanyang xian wenshi ziliao 南陽縣文史資料 7,1993,p. 108-131. 
SHU Xinchen 舒新城 (comp.), Jindai Zhongguo jiaoyu shi ziliao 近代中國教育史資 料, 3 vols, Beijing, Renmin jiaoyu chubanshe, 1962.

SHur Puci 水普慈, “Liu Zhenhua zai Nanyang” 劉鎮華在南陽, Henan wenshi ziliao 河 南文史資料 48, 1993, p. 157-159.

Su Yunfeng 蘇雲峰, Zhang Zhidong yu Hubei jiaoyu gaige 張之洞與湖北教育改革, Taipei, Institute of Modern History, Academia Sinica, 1976.

Taishang lü mai yuanliu Longmen chuanjie puxi 太上律脈源流龍門傳戒譜系, handscroll held at the White Cloud Monastery, Beijing.

WANG Baoqing 王保卿, “Xuanmiao guan zhuchi Yao Aiyun fufa de jingguo 玄妙觀住 持姚雹雲伏法經過,” Nanyang wenshi zhiliao 南陽文史資料 2, 1986, p. 25-27.

WANG Leiquan 王雷泉, “Dui Zhongguo jindai liangci miaochan xingxue de fansi” 對 中國近代兩次廟產興學的反思, Fayin 法音 4, 1994, p. 14-19.

WANG Pengzhou 王鵬洲, “Xie laodao qicheng ziqiang ji” 謝老道棄城自戕記, Nanyang xian wenshi ziliao 南陽縣文史資料 6, 1992, p. 59-64.

WANG Xinchang 王新昌 \& Tang Minghua 唐明華 (eds.), Yisheng Zhang Zhongjing yu Yisheng ci wenhua 醫聖張仲景與醫聖祠文化, Beijing: Huayi chubanshe, 1994.

Welch Holmes, The Buddhist Revival in China. Cambridge, Harvard University Press, 1968.

Wright Mary C., The Last Stand of Chinese Conservatism: The T'ung-chih Restoration, 1862-1874, Stanford, Stanford University Press, 1957.

Wu Chunmei 吳春梅, “Qing mo Xinzheng shiqi de nongye gaige”清末新政時期的農 業改革, Zhongguo nongshi 中國農史 3, 1999, p. 43-47.

Wu Liquan 吳麗泉, “Wo de pengyou Peng Yuting” 我的朋友彭禹廷, Henan wenshi ziliao 河南文史資料 14, 1985, p. 11-16.

- - , “Nanyang Jin'gang Ximan zhongxue” 南陽靳崗西滿中學, Henan wenshi ziliao 河南文史資料 14, 1985, p. 165-167.

XI Zheng 席正, “Nanyang Xuanmiao guan” 南陽玄妙觀, Nanyang xian wenshi ziliao 南陽縣文史資料 1, 1987, p. 58-60.

Xu Jingyu 徐靜玉, “Zhang Jian yu Qingmo nongye gaige” 張謇與清末農業改革, Hunan nongye daxue xuebao 湖南農業大學學報 1, 2003, p. 39-42.

XuE Youliang 薛友諒, “Qiyun Wang zhenren kai Laoshui ji” 棲雲王真人開澇水記, in CHEN Yuan 陳垣 and CHEN Zhichao 陳智超 (eds.), Daojia jinshi lue 道家金石略, Beijing, wenwu chubanshe, 1988, p. 620-621.

YAN Heyi 嚴合怡, Daotong yuanliu 道統源流, Wuxing, Daotong yuanliu bianji chu, 1929.

YANG Tingbin 楊廷賓, “Ji Nanyang Yangshi jiazu” 記南陽楊氏家族, Henan wenshi ziliao 河南文史資料 33, 1990, p. 158-75.

YIN Dejie 尹德傑, Lao Nanyang 老南陽, Zhengzhou, Henan renmin chubanshe, 2005.

ZHANG Baixi 張百熙 et al., Zouding xuetang zhangcheng 奏訂學堂章程, Wuchang, Hubei xuewu chu, 1903.

ZHANG Fang 張昉, “Wo suo zhidao de Zhao Ti” 我所知道的趙惕, Nanyang wenshi ziliao 南陽文史資料 31, 1989, p. 1-16.

ZHANG Kaiyuan 章開沅 \& TIAN Tong 田桐, Zhang Jian yu jindai shehui 張謇與近代社 會, Wuhan, Huazhong shifan daxue chubanshe, 2001. 
Zhenping xian zhi 鎮平縣志, Beijing, Fangzhi chubanshe, 1998.

Zhou Dianjun周殿君, “Suotan Nanyang shangye” 瑣談南陽商業, Nanyang xian wenshi ziliao 南陽縣文史資料 6, 1992, p. 96-106.

\section{Chinese Character List}

Baxian gong 八仙宮

baohu ling 保護令

cansang xuetang 辟桑學堂

cangjing ge 藏經閣

Changchun guan 長春觀

Chen Mingbin 陳明霖

Chongzheng gaodeng xiao xuetang 崇正高等小學堂

Chongzheng shuyuan 崇正書院

chudeng xiaoxue 初等小學

culiang 粗糧

daoji si 道紀司

damiao 打廟

danqian 丹錢

Danxia si 丹霞寺

Dengzhou 鄧州

Dushan Zushi gong 獨山祖師宮

Duolong'a 多隆阿 (literary style: Litang 禮堂)

fazhan nongye hezuo 發展農業合作

Feng Yuxiang 馮玉祥

gaodeng xiaoxue 高等小學

gongtian 公田

guojiao 國教

Ge Yuetan 葛月潭

Guo Zhixian 郭至賢

Huijia Zhongzhou 惠浹中州

jianyuan監院

Jin ye xiao xuetang 敬業小學堂

Jiuji xiaoxue 救濟小學

Kang Youwei 康有

Khubilai 忽必烈

Li Hongzhang 李鴻章

Li Zongyang 李宗陽

Long Hai xian 隴海線

Meixi hezuo nongchang 梅溪合作農場

Meixi nongchang nantong xunlian ban 梅溪農場難童訓練班

Meixi nongchang yiyao shishe suo 梅溪農場醫藥施舍所 
miaochan xingxue 廟產興學

mopan dan 磨盤單

$\mathrm{mu}$ 畧

Nanyang 南陽

Nanyang quan gong chang 南陽勸工廠

Nanyang xiyi suo 南陽習藝所

Nanyang xian Daojiao hui 南陽縣道教會

Nanyang zongzhen 南陽總鎮

Neixiang 內鄉

Nie Xiaoxia 聶嘯霞

Nonggong shiye xuetang 農工實業學堂

Pingmianbu 平棉布

Ping Han xian 平漢線

Puti si 菩提寺

Qiangxue hui 強學會

qing 頃

Quanxue pian 勸學篇

Quanxue suo 勸學所

Quanzhen 全真

Quanzhen guangxue 全真廣學

renzini 人字呢

Sancui xiaoxue 三萃小學

Sanjiao tang 三教堂

Sanyuan gong 三元宮

Shanghai jiusheng hui 上海救生會

shangye xuetang 商業學堂

Shaohuai xiaoxue 少懷小學

Shenghai gong 聖海宮

shifang conglin十方叢林

shixing jiti shengchan 實行集體生產

shiye xuetang 實業學堂

Shui Puci 水普慈

Si zhuang 寺莊

sishu 私塾

Taiqing gong 太清宮

Tanggu 塘沽

Tongmeng hui 同盟會

Tongzhi zhongxing 同治中興

tumianbu 土棉布

tuiguang youliang pinzhong 推廣優良品種

Wang Zhe 王喆 (style: Chongyang 重陽)

Wuhou ci 武侯祠

Wu Liquan 吳麗泉

Wei Shaopo 魏少坡 
Liu Xun

Xichuan 淅川

Xie Baosheng 謝寶勝 (literary style: Zilan子蘭)

Xuanmiao guan 玄妙觀

Xuanmiao guan liangdeng xiaoxue 玄妙觀兩等小學

Xuebu 學部

xuetian 學田

Yang Heting 楊鶴汀

Yao Xiangrui 姚祥瑞 (also known as Yao Aiyun姚藹雲)

Ye'an 葉庵

Yilin huiguan 醫林會館

Yisheng ci 醫聖祠

yixue 義學

youji 遊擊

Yu Yinlin 余蔭霖

Yuanzong xuetang 元宗學堂

Zeng Guofan 曾國藩

Zhang Jiamou 張嘉謀

Zhang Zhidong 張之洞

Zhang Yuanxuan 張圓瓐

Zhenping 鎮平

Zhenwu 真武

Zhongyang Daojiao hui 中央道教會

zizhi yundong 自治運動

Zushi 祖師 